\title{
THE QUESTION OF QUESTIONS: WHAT IS A GENE? COMMENTS ON ROLSTON AND GRIFFTHS \& STOTZ
}

\begin{abstract}
If the question "What is a gene?" proves to be worth asking it must be able to elicit an answer which both recognizes and address the reasons why the concept of the gene ever seemed to be something worth getting excited about in the first place as well analyzing and evaluating the latest develops in the molecular biology of DNA. Each of the preceding papers fails to do one of these and sufferrs the consequences. Where Rolston responds to the apparent failure of molecular biology to make good on the desideratum of the classical gene by veering off into fanciful talk about "cybernetic genes,"

Griffiths and Stotz lose themselves in the molecular fine print and forget to ask themselves why "genes" should be of any special interst anyway.
\end{abstract}

KEY WORDS: Aristotle, telo, final cause, formal cause, epigenesis, preformationism, information, cybernetic genes, Gene-P, Marfan Syndrome, nominal genes, instrumental genes, Kirshner and Gerhart, West-Eberhard

The answer to a philosophical question can lead to many different outcomes: fundamental insights into states of affairs, uncovering of conceptual confusions and fine-tuning of conceptual boundaries, or the turning-over of stones that had hitherto held their ground. Sometimes, however, the shortcomings of answers may lead to a higher (or more "meta") level of reflection on why it may have been the wrong question to ask in the first place. The idea of the gene has long, and always, been about grasping something fundamental about the living organism - which is also to say that it does not merit any intrinsic interest outside the context of what it reveals about the living organism. Other than perhaps as a historical reflection, from within a discipline, on the rise and fall of its distinctive concepts, the interest in the concept of the gene is accountable and subordinate to what if any 
value it has for biology. I will argue that the papers by Rolston and by Griffiths \& Stotz are revealing most of all in this latter sense. Inasmuch as neither succeeds in offering an account of the concept of the gene that is simultaneously both lucid and interesting in relation to the "big questions" of biology, we are provoked to wonder whether the problem may pertain to the question being asked itself.

The apparent enigma of the gene can only adequately be appreciated from a very wide angle. The point of departure for systematic and explanatory accounts of the living world, i.e., biology (albeit before it was called such) was the work of Aristotle. Explicitly Aristotelian biological enterprises, such as that of Georges Cuvier, continued well into the $19^{\text {th }}$ century. Even if some combination of Darwin and Mendel, or perhaps Darwin, Mendel, and Watson \& Crick, have finally rendered any vestiges of Aristotle's approach incorrect (as many champions of $20^{\text {th }}$ century biology have held), or even just redundant, it would still be useful to know just what it is that we can now answer 2,000 years later that Aristotle could not. What are the central problems that have occupied these millennia of biological inquiry to which the solutions of genetic Darwinism must be held accountable?

For present purposes, I want to pick out from Aristotle two important insights he got right. Aristotle recognized that living beings, organisms, must be understood in all respects as ends-untothemselves. What they do, how they are, how they develop and change can only be understood as being neither random and accidental, nor for the sake of some other good, but only with respect to the realization of their own good (or telos) - that is, in terms of their very existence as their own ultimate end. Aristotle's sense of final cause captures what microbiology and cell biology have more recently come to recognize about even single cells: that even microscopic cells can be trained to sustain fluctuations in heat, ionic concentration, toxic exposure, and other such challenges, i.e., that even single cells exist and act as ends-unto-themselves in ways that we have yet to exhaustively catalog and explain. The other point that Aristotle got right was that biology could not be explained reductively on the basis of the properties of elemental matter as his time understood these to be. Aristotle's solution was not to appeal to a transcendent cause but rather to be a kind of holist about nature. Nature was understood to be possessed of local purposes. Whereas the final cause of an artifact, such as a table, is given to it by the artisan (and by those who use it as a table), the final cause of an organism is present 
within itself and it is inseparable from its formal cause (its phenotypic form). Organisms, as it were, give themselves their form for the sake of their own ultimate good as the kinds of beings they are. Final and formal causes thus impose themselves upon matter, i.e., upon material cause. Matter takes the shape it does, and changes as it does, for the sake of attaining the final good of being a certain kind of organism.

The problem with Aristotelian biology begins when we can no longer "metaphysically" countenance the idea that final cause can exist within nature (except perhaps for humans). Seventeenth century biologists did not invert the dominance of form and finality over matter. They simply lifted the latter up into the realm of the transcendent (creator-god), by way of multiple versions of preformationism. (Amundson, 2005) The real challenge for a post-seventeenth century, non-creationist biology has been that of explaining the "finality of life" that Aristotle got right on the basis of some new and enhanced understanding of material cause. This would be the realization of a Copernican Revolution in biology.

Much, if not all, of the subsequent history of biology can be seen as attempts to reconfigure Aristotle's four causes within the constraints of modern metaphysical assumptions about nature. Preformationism, as set forth by Jan Swammerdam, (Darwin, 1998) for whom the finality of form was provided at creation, could then separate the dynamics of the unfolding of form from questions of finality and thus study formal cause on its own. This led to further work of nineteenth century morphologists who sought to grasp the logos of biological form and its transformations. Linnaeus's taxonomy can also be seen as a work on form pulled apart from finality, and indeed it was the formal classificatory systematics of the early $18^{\text {th }}$ century that led to the morphological enterprises of the late $18^{\text {th }}$ and early $19^{\text {th }}$ centuries. (Kant, 1987) Against the objections of his neo-Aristotelian adversary Buffon, Linnaeus's taxonomy did not attempt to reveal the core of an organism's way of being (its final cause). It only sought to provide a serviceable method of classification, assuming however that the tableau of the living world, the final cause of the ordering of living beings, its "logos" was provided from "above," as it were, by transcendent design. Epigenesists, such as Buffon and Needham, (Kirchner and Gerhart, 2005) who remained true to the inseparability of formal with final cause, tried to solve the problem in a Newtonian spirit at the level of efficient cause. If Newton could make action at a distance scientifically acceptable, 
then perhaps some form of organizational or formative force could likewise bring final cause back into the nature of the beast. Such efforts were of course ultimately ridiculed as "vitalisms." It was then Immanuel Kant who both re-articulated a version of the Aristotelian insight into the irreducibly "self-purposive" character of the living organism and simultaneously disavowed the possibility of it ever being explained on the basis of material (and/or efficient) cause-hence his famous proclamation that there would "never be a Newton of a blade of grass." (Moss, 2003)

The widespread conviction (albeit largely tacit) that Kant has been "disproved" and that twentieth century biology has succeeded in explaining life on a 'material basis' turns on two central pivots-Darwinism and the idea of the gene. Darwin himself, however, said no such thing. Darwin offered part of an account of how adaptive form can result from material conditions, but only in part. He proposed a theory subject to "the laws of generation and variation"- -laws that he could neither provide nor purge of any trace of final cause: so conceived, the evolution of new and adaptive form could and would come about through "natural selection." (Nordenskiöld, 1928) Whether the processes of generation and variation (and thus evolution by natural selection) could be fully accounted for on a non-teleological material basis was left an open question. But Darwin was no Darwinian zealot. For Darwin, it was, in any event, also the case that the "final cause" of the organism did in fact play a direct role in the subsequent evolution of form since aesthetic preference (sexual selection) and force of habit were both understood to be forces of evolutionary change. (Ospovat, 1981)

If one takes it as an unquestioned, albeit often tacit, given that contemporary biology has succeeded in explaining life in all its forms and without recourse to any "illicit" notions of immanent final cause, then one can begin to appreciate the burden that weighs upon the concept of the gene and to understand a motivating source of some of the stark peculiarities of Rolston's article on the concept of the gene.

To begin with, Rolston's philosophical analysis of the concept of the gene is not very philosophical at all. Whereas philosophers see inconsistent claims as provocations that must be analyzed, challenged, and overcome, journalists see the same as evidence of the achievement of balance and neutrality - the fair representation of all sides. Ostensibly, Rolston then writes in the style of the journalist. At first he steps back and lets the professionals do the talking, but what the professionals have to say is often inconsistent. Development, we 
are told, has proven to be modular, and so is indeterminate with respect to any of its modular parts which in themselves may contribute to alternative phenotypic outcomes. Nonetheless, preformationistic genetics has always assumed that traits are determined by discrete modular parts (genes), so (somehow) everything is fine. Is Rolston just so blissfully ignorant of cell and developmental biology that he does not get the problem or is this a rhetorical sleight of hand in the service of an as yet to be revealed agenda? After amply acknowledging the impossibility of even definitively individuating genes (defining the boundaries of genetic units) at a material level (as segments in DNA), he turns in a surprising direction that reveals his larger intentions. What could not be said univocally at the material/ empirical level can suddenly be espoused with certainty at the more formal-ethereal level of "information." No longer deferring to the voices of others, Rolston now proclaims that: "A gene is a cybernetic unit, an information fragment. What is conserved is not the matter, not the organism, not the somatic self, not even the genes, but a message that can only be conserved if and only if it is distributed, disseminated. That may be the sine qua non of any complete account of what a gene is." Having stepped away from the muck of matter, far-reaching ontological claims can now come fast and furious. While at the empirical/molecular level we know that a single stretch of coding DNA on a chromosome may provide the template resource for potentially hundreds or thousands of downstream RNA and/or protein products, it is thus problematic at least to refer to a gene as "representing" any one immediate outcome. Having moved to this more ethereal level, Rolston begins to describe representation in almost spiritual terms: "The organism instantiates its genetic types; survival of the gene type is what counts. Its genes code the kind, representatively; and the organism, an expression of the kind, presents and re-presents the kind in the world."

Eventually Rolson's discussion of the "cybernetic" gene is just as inconsistent and equivocal (or perhaps journalistically "balanced") as his earlier, ostensibly second-hand account of Mendelian and molecular genes. Cybernetic genes encode "how to live on land or how to nurse a baby," and yet "the organism selects what to play, and improvises on the themes, cutting and splicing here and there, depending on the circumstances and needs of the organism." It is now the organism that is the reader and the genome that is merely a stereotyped script, or the organism that is a cook and the genome merely a recipe. "Cybernetic genes are open as much as they are 
deterministic," but then again "Genes carry the information that the elk should flee the approaching hunter or that the plant should secrete repair products and rebuild roots prospective to survival through the winter" (even if genetics cannot yet provide a taxonomy of such information). So why then make the move at all toward the immateriality of the cybernetic gene and its information and representations, thereby (more than) risking a descent into nonsense and vapid flights of fancy? The give-away clue can be found in Rolston's own hand: 'What genes have is a 'telos,' an 'end.' Magmas crystallizing into rocks, and rivers flowing downhill have results but no such 'end.' Organisms are biological agents; the phenotypes are doing something, maintaining their form of life; and they succeed because within them are genes which are also biological agents, doing something, maintaining this form of life. Genes are proactive."

Rolston, we can now see, is caught in a contemporary dilemma. The living organism, as Aristotle observed, is characterized by being an end-unto-itself. Rolston, too, understands this. But contemporary biology, or at least some of its ideologues and journalists, have proclaimed that we have long since eradicated the challenge of teleology by accounting for it on a material basis, i.e., that of the gene. But the materiality of the gene, i.e., molecular biology, reveals no such thing. Analysis of the molecular gene has not provided the laws of generation and variation relevant to evolutionary change - rather it has revealed the limits of looking at DNA alone. Insights into the developmental basis of evolutionary variation are beginning to emerge from studies in cell and developmental biology but are far from complete. To the extent that cell biology and evolutionary-developmental ("evo-devo") biology always presuppose a preexisting purposeful cell, the complete materialization of final cause will in fact continue to be a desideratum for some time to come. Rolston has simply followed a well-traveled path with antecedents going back to the seventeenth century. Where our grasp of material cause is not adequate to explain the finality of the living organism, a transcendent formal (and final) cause, now called information or the cybernetic gene, is hypostatized. It is the genes, as Rolston tells us, that "have a telos."

Rolston's justification for elevating genes to the level of immaterial, cybernetic/informational quasi-agents is that George C. Williams and John Maynard Smith said it was so. But why would any biologists be tempted to think that this could be a scientifically tenable view? I have argued in earlier work ${ }^{1}$ that this temptation is rooted in a tendency to 
conflate two different senses of the gene, each of which is valid in a certain disciplinary domain, but with the proviso that nothing or almost nothing counts as a gene simultaneously in both senses. Gene-P, I claim, is the sense of a gene when it is defined by a predictive relationship to a phenotype, but a Gene-P is indeterminate with respect to its material basis (i.e., its DNA sequence) for reasons I will discuss soon. So any gene that is a "gene for" (such as the BRCA-1 gene for breast cancer, or the gene for blue eyes, or the gene for Marfan syndrome) would count as a Gene-P. Gene-D by contrast is the sense of a gene when it is defined by a nucleic acid sequence that provides the template resource (or information) for some set of potential downstream polypeptide and/or RNA products. But Gene-D is indeterminate with respect to phenotypic outcome just because between variable splicing, co-and post-translational modification, targeting, and many other contextual factors, the same Gene-D could be a contributing factor to entirely different, even antithetical, phenotypic outcomes. If this is correct then the only way to construe a gene as being both a specific and defined molecular sequence and to have a specific and defined phenotypic outcome is to conflate these two independent and non-overlapping senses of the gene. The gene construed by Dawkins (his selfish gene or "replicator") and that of all those with very similar views (George C. Williams and John Maynard Smith perhaps?) are just such conflations.

How, one may well ask, can a Gene-P have a predictable phenotypic outcome without having a determinate nucleic acid sequence? Would it not just be a matter of finding the relevant sequence? To understand Gene-P, one must step back from what has become conventional wisdom or expectation. Gene-P phenomena are based on the absence of an otherwise normal protein or other resource and what bodies will predictably do, for better or for worse, in the absence of that normal resource. Gene-P for blue eyes is not information for making blue eyes - it is simply the absence of a necessary resource for producing brown eye pigment and blue eyes are what result, they are what developing human bodies do under such circumstances. There are surely many ways of not having the right sequence resources for making brown eye pigment and any of those variations would show up as a gene for blue eyes. Another, perhaps more striking example is that of Marfan Syndrome. Marfan Syndrome was characterized first by the presence of exceptionally long and tapering fingers and toes. There are many other characteristics that have come to be associated with it as well (including an enhanced 
susceptibility to aortic aneurisms). Marfan syndrome occurs when a protein called fibrillin-1 fails to be incorporated into the bodies' connective tissue. Any genetic lesion which blocks the incorporation of fibrillin-1 into connective tissue (including mutations in the fibrillin-1 sequence that prevent its expression) will show up as a gene for Marfan Syndrome. But no amount of inquiry into the "information" encoded in Gene-P for Marfan syndrome will reveal anything about how bodies make long tapering fingers and toes. Genes-P open windows onto the processes of phenotypic plasticity of the developing organism and, understood properly, could become invaluable clues into complex and systematic capacities of the phenotype (and the developmental and dynamic etiology of many diseases). But for those who are perhaps overly eager to find proof that science has overcome all the challenges of reconciling final cause with the metaphysical constraints of a post-teleological nature, Gene$\mathrm{P}$ merges with Gene-D producing the illusion of a formal cause written into the genetic code but transcending its materiality. It is only the conflation of Gene-P with Gene-D that might appear to "have a telos." What has been abstracted-out and elevated to an ethereal, formal status by Rolston is the very material capacity of developing organisms to respond and adapt plastically (albeit not always successfully) to both internal and external challenges - capacities that we simply do not fully understand as yet.

Philosophically, what should it mean to address the question "what is a gene?" If Rolston felt that it meant to claim, or vindicate the claim, that genetics has solved one of the great metaphysical problems of modern times - even if it meant a departure from argumentative rigor-Griffiths and Stotz proceed as if that nature of the task were a done deal, requiring no reflection on questions of higher level biological meaning or import, but simply a bloodless exercise in micro-distinction and making definitions. After a sizeable review, Griffiths and Stotz leave us with the result that molecular genes are defined in retrospect of a sequence discerned to be used as the template for some down-stream products - except when they are not (in which case they are "nominal" genes). If this were all there was to be said about the meaning of "gene," would it suggest anything about the larger questions of biology or even about whether "what is a gene?" is the right philosophical question to ask? The Griffths and Stotz paper is clearly not about such reflections but rather is about business as usual. The business-as-usual of biologists, its seems, just is about using the word gene, and the business-as-usual 
of philosophers just is analyzing what biologists mean when they use the word gene. Surely all disciplinary texts entail a performative dimension. Not only do they make a claim about some state of affairs in the world - implicitly and enactively they also make a claim about what it is to work within a certain discipline and to make claims from within that discipline. Surely if "the gene" means no more than Griffiths and Stotz suggest, then we must wonder why we would ever have asked this question to begin with, or what it means for genes to mean so little when everyone seems to assume otherwise, or what the better questions to ask would have been. But Griffiths and Stotz fail to notice this elephant in the room that they have just decorated. The performative thrust of their article seems to be something about philosophers of science getting the (essentially technical) jobs done, elephants not withstanding.

So is "what is a gene?" the right question to ask? I have suggested that the cardinal challenge in scientifically understanding life has not changed since Aristotelian Day One, i.e., accounting for the finality of living organisms as material beings, and have argued that one cannot appreciate what the great interest in "genes" has been without appreciating how genes have been perceived in this larger context. If "what is a gene?" is to be an interesting question, it is only by leading us to understand how we are currently attending to the big picture and by pointing in those directions whereby our next inroads are most likely to be made. Rolston and Griffiths \& Stotz have demonstrated two of the wrong ways of approaching the question and thus of the liabilities of asking this question itself. Where Rolston has inflated the concept of the gene with helium and described its ascent into the heavens, Griffiths \& Stotz have deflated it down to where it can be aliquoted onto a 96 well plate and analyzed spectrophotometrically, and have insinuated that this is what hard-working philosophers are meant to do for a living.

Must an analysis of the gene concept necessarily miss the mark of that big picture that makes "what is a gene?"- a question potentially worth asking to begin with? Inasmuch as the gene concept has been the leading conceptual device through which $20^{\text {th }}$ century biologists have attempted to grasp at the inner springs and principles of the organism, an adequate analysis of its current status should in fact lead us to understand the state of the science, or perhaps at least to know where else to look. Griffiths \& Stotz claimed to have identified three senses of the gene, three gene concepts, the first "instrumental" and the other two "molecular." Had they pursued this line of inquiry, 
they might have been led to more sure-fire results. But in practice what they did was to squint their eyes and see only their molecular gene or genes which they could then treat as a narrow and primarily technical problem in conceptual microanalysis divorced from all of those big questions about life that had ever made genetics an exciting enterprise. The idea of "an instrumental gene" bears a superficial resemblance to a Gene-P, but as a Gene-P it is eviscerated and confused. What exactly Griffiths and Stotz mean by instrumental genes playing a "critical role in the construction and interpretation of a range of experiments in which the relationship between genotype and phenotype is explored via hybridization between organisms or directly between nucleic acid molecules," one can only wonder. Whatever it is, it is clearly meant to relegate the gene-for-phenotype sense of the gene concept to some very remote left field where it can be easily ignored. But the interest in genes has always been associated with the gene-for effect because this is where there appeared to be a way to grasp at the complex and apparently purposive capacities of the organism. Conflating this with molecular genes was the wrong way to go but once this error has been exposed, Gene-P phenomena can be set loose as an invaluable point of entry into real biology. We are starting to develop the conceptual vocabulary for such understanding. It is Gene-P phenomena that can now be most readily associated with the developmental phenotypic plasticity of living organisms that are based on the presence of conserved core modular processes, and the earlier compartmentalization of the embryo, which can respond to either an external (environmental) or an internal (e.g., Gene-P) perturbation, symmetrically, through restructuring modular interactions. The modular developmental architecture of the organism allows us to understand how mutations can both be buffered and compartmentally delimited, yet also how they their phenotypic consequences can be amplified, thus making Gene-P effects possible (and comprehensible). Kirschner and Gerhart (Roe, 1981) refer to this as "facilitated variation." Mary Jane West-Eberhard, (Shapiro, in press) whose four-step evo/devo model of phenotype-first evolution contains two distinct roles for genes, one which is Gene-P like, and the other which is Gene-D like, terms the capacity of an organism to parlay entirely different phenotypic patterns "developmental recombination." The concepts of facilitated variation and developmental recombination first give us the tools for understanding the possibility of (unconflated) Gene-P phenomenon, the thousands of actual types of Gene-P phenomena provide cellular, developmental, and 
evolutionary-developmental biology with invaluable resources for fleshing out the actual dynamics of phenotype transitions.

Finally, even at the level of Gene-D, Griffiths \& Stotz missed the (at least more interesting) boat. What is progressively emerging as perhaps the most surprising and revolutionary characteristic of DNA is the ability of that major part of the genome described as "transposable" to move, expand, modify, and systematically restructure the genome and its proclivities. Where most of the fancy bells and whistles pertaining to splicing and other coding-regulatory phenomena are derived from eukaryotes, the self-triggering mobility and transformability of DNA was already pervasive in prokaryotes and is thus coextensive with life as we know it and its apparent finality. (West-Eberhard, 2003)

If the question "what is a gene?" is bound to bias thinkers and readers away from dynamic genomes and flexible phenotypes and toward "coding regions" (or their "nominal" surrogates), then it is fair to say that "what is a gene?" is indeed the wrong question to ask.

\section{NOTE}

1 Online Mendelian Inheritance in Man (OMIM), (http://www.ncbi.nlm.nih.gov/ entrez/query.fcgi?CMD $=$ search\&DB $=$ omim), Accessed on September 4, 2006.

\section{REFERENCES}

Amundson, R. The Changing Role of the Embryo in Evolutionary Thought: Roots of Evo-Devo. Cambridge: Cambridge University Press, 2005.

Darwin, C. The Descent of man. Amherst: Prometheus Books, 1998.

Kant I. Critique of Judgment. Translated by W.S. Pluhar. Indianapolis: Hackett Publishing Co., 1987.

Kirschner, M. and J. Gerhart The Plausibility of Life: Resolving Darwin's Dilemma. New Haven: Yale University Press, 2005.

Moss, L. What Genes Can't Do. Cambridge: The MIT Press, 2003.

Nordenskiöld, E. The History of Biology. New York: Tudor Publishing Co., 1928.

Ospovat, D. The Development of Darwin's Theory: Natural History, Natural Theology, and Natural Selection, 1838-1859. Cambridge: Cambridge University Press, 1981.

Pinto-Correia, C. The Ovary of Eye. Chicago: University of Chicago Press, 1997.

Shapiro, J. "Bacteria are Small but not Stupid: Cognition, Natural Genetic Engineering, and Sociobacteriology." In Studies in History and Philosophy of Biological and Biomedical Sciences. (In Press). 
Roe, S.A. Matter, Life, and Generation: 18th century Embryology and the Haller-Wolff Debate. Cambridge: Cambridge University Press, 1981.

West-Eberhard, M.J. Developmental Plasticity and Evolution. Oxford: Oxford University Press, 2003.

Department of Sociology \& Philosophy and ESRC Center for Genomics in Society

University of Exeter Amory BLDG,

Rennes Dr., Exeter

Devon, EX44RJ

$U K$

E-mail:Lenny.Moss@exeter.ac.uk 